\title{
Processing Techniques and Formability of Age-hardenable, Low Yield, High Tensile Strength Cold-rolled Sheet Steels*
}

\section{By Nobuo ŌHASHI,** Isao TAKAHASHI** and Kouichi HASHIGUCHI**}

\begin{abstract}
Synopsis
Continuously annealed high strength cold-rolled sheet steels of a special type having tensile strengths of 40 to $70 \mathrm{~kg} / \mathrm{mm}^{2}$ have been developed. These sheet steels contain $0.05 \% \mathrm{C}-1.2 \% \mathrm{Mn}-0.5 \% \mathrm{Cr}$ as main components and have a "dual phase" (ferrite and transformed product) microstructure which is obtained by short time annealing at temperatures above $A_{1}$ and subsequent rapid cooling at the rate of 5 to $50^{\circ} \mathrm{C} / \mathrm{sec}$. The mechanical properties of these sheet steels are characterized by a low yieldto-tensile strength ratio below 0.6 in as-annealed condition and a strong age-hardenability at the temperature of about $200^{\circ} \mathrm{C}$.

The effects of processing variables on the tensile properties together with good press-formability and shape-fixability of these sheets are proved.
\end{abstract}

\section{Introduction}

In recent years, the demand for high strength coldrolled sheet steels for automobile use has been steadily increased because of the necessity for satisfying the safety standards with increasing severity and the request for the reduction of vehicle weight by use of thinner gage sheet steels to minimize energy consumption.

Ductility of steel generally decreases with increase in strength, so that the selection of proper alloying elements and manufacturing process are essentially important to strengthen steel without impairing ductility. Solid solution hardening by increasing the contents of carbon, silicon, and/or manganese and precipitation hardening and/or grain refinement by adding niobium, titanium, and/or vanadium are primarily useful methods for strengthening of steels. If the box-annealing process is applied to produce these types of steel, however, large amounts of alloying elements have to be added, which inevitably result in inferior formability, poor ductility, low work hardening rate, and low plastic strain ratio. ${ }^{1)}$ High yield strengths of these steels also deteriorate the shape-fixability of the automobile parts with larger radius of curvature on press forming. ${ }^{2)}$

From these points of view, studies to develop steels of low yield and high tensile strengths have been conducted using low $\mathrm{C}-\mathrm{Mn}-\mathrm{Cr}$ steels and applying continuous annealing process. As the results of these studies, the new sheet steels having low yield strengths and high tensile strengths of 40, 50, 60 and $70 \mathrm{~kg} / \mathrm{mm}^{2}$ have been developed. A remarkable bake-hardenability at the temperature range of $200^{\circ}$ to $400^{\circ} \mathrm{C}$ after deformation is the characteristics of these steels and can contribute strengthening the pressed parts on the baking process after painting. ${ }^{3,4)}$ This paper deals with the manufacture techniques and the properties of these steels.

\section{Characteristics of Sheet Steel of Low Yield and High Tensile Strengths}

A typical stress strain curve of such steel as described above, which has no discontinuous yield drop, is shown as the curve a in Fig. 1. The yield strength defined as the flow stress at the $0.5 \%$ strain under loading is about $20 \mathrm{~kg} / \mathrm{mm}^{2}$ which is less than $50 \%$ of tensile strength of the sheet in as-annealed condition, and this means very high work hardening rate at the small strain region in the stress strain relationship. When the as-annealed sheet is aged at medium temperature, for example at $400^{\circ} \mathrm{C}$, without giving deformation, yield drop clearly appears and yield strength increases as shown as the curve b in Fig. 1. Aging at the temperatures less than about $200^{\circ} \mathrm{C}$, however, does not change the tensile properties of as-annealed sheet, so that the aging at room temperature gives no stretcher strain on press-formed parts. On the other hand, aging at about $250^{\circ} \mathrm{C}$ after straining sharply increases yield strength as well as tensile strength (the curve c in Fig. 1) and this " accelerated aging " ${ }_{51}$ behavior can be effectively utilized to strengthen the pressed parts during subsequent paint

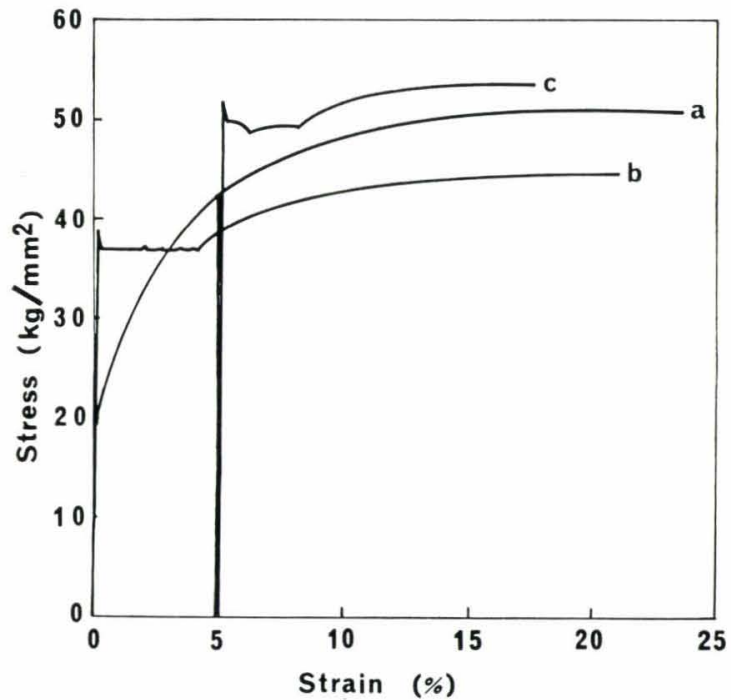

(a) as-anneald (b) aged at $400^{\circ} \mathrm{C}$ for $20 \mathrm{~min}$

(c) aged at $250^{\circ} \mathrm{C}$ for $20 \mathrm{~min}$ after tensile straining by $5 \%$

Fig. 1. Stress-strain curve of the sheet steels after treatments in three different conditions

* Originally published in Journal of Japan Society for Technology of Plasticity, 17 (1976), 883, in Japanese. English version received May 24, 1977.

** Research Laboratories, Kawasaki Steel Corp. Kawasaki-cho, Chiba 280 
baking process.

\section{Effect of Annealing Conditions on Tensile Properties}

On the cold-rolled sheet steels, chemical compositions of which are $0.05 \% \mathrm{C}-1.2 \% \mathrm{Mn}-0.01 \% \mathrm{~N}$ with or without $0.5 \% \mathrm{Cr}$, the effect of the short time annealing condition on the tensile properties has been studied.

\section{Annealing Temperature}

The specimens of $0.8 \mathrm{~mm}$ thick are annealed at the temperatures between $700^{\circ}$ and $950^{\circ} \mathrm{C}$ for $30 \mathrm{sec}$ and cooled at the rate of $8^{\circ} \mathrm{C} / \mathrm{sec}$ to room temperature. Effect of annealing temperature on the tensile properties is shown in Fig. 2. The tensile properties of Cr-free steel does not depend on the annealing temperature and are characterized by high yield-to-tensile strengths ratio. Those of $0.5 \% \mathrm{Cr}$ steel, however, are influenced by the annealing temperature. The stress strain curve of the steel annealed at $700^{\circ} \mathrm{C}$ has a sharp yield drop and large yield elongation. After the annealing at $750^{\circ} \mathrm{C}$, the yield elongation and yield strength clearly decrease than those annealed at $700^{\circ} \mathrm{C}$ while the tensile strength increases. After the annealing at higher than $800^{\circ} \mathrm{C}$, however, the yield strength gradually increases while the tensile strength and the yield elongation are unchanged and total elongation slightly decreases. The stress strain curve of the steel annealed at $800^{\circ} \mathrm{C}$ is the curve a in Fig. 1. In spite

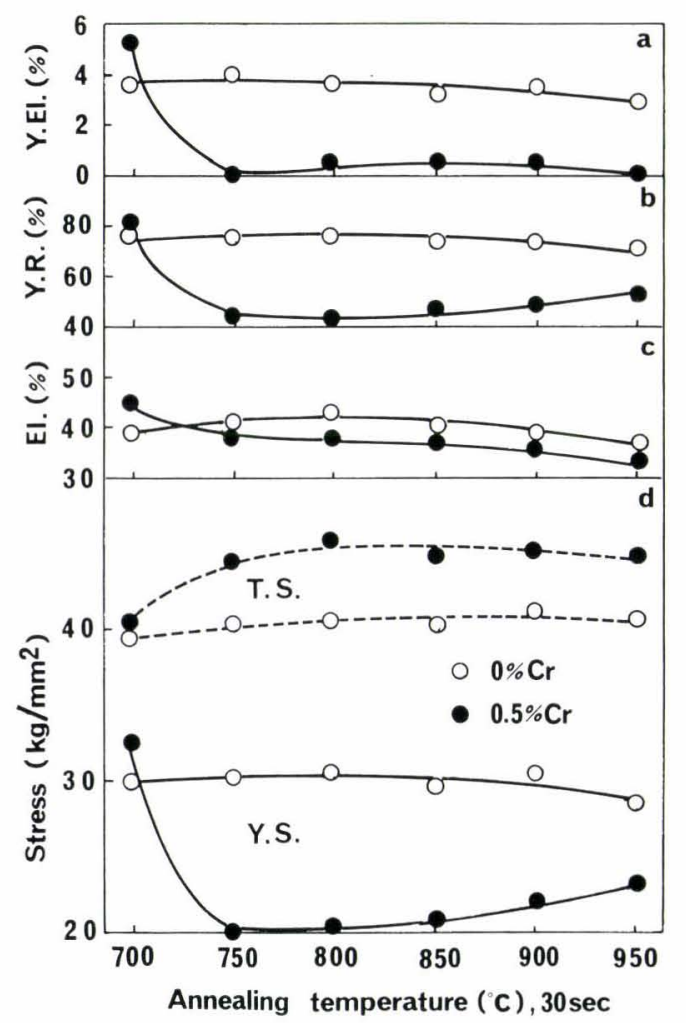
(a) yield elongation
(c) total elongation
(b) yield ratio
(d) tensile strength and yield strength

Fig. 2. Effects of annealing temperature and Cr content on the tensile properties of the high tensile strength of $45 \mathrm{~kg} / \mathrm{mm}^{2}$, yield strength is only 20 to $23 \mathrm{~kg} / \mathrm{mm}^{2}$ which is comparable to that of mild steel.

\section{Cooling Rate}

Effect of cooling rate after annealing at $800^{\circ} \mathrm{C}$ for $30 \mathrm{sec}$ on the tensile properties is shown in Fig. 3. For $0.5 \% \mathrm{Cr}$ steel, there exists a wide cooling rate range which gives low yield-to-tensile strengths ratio. As for Cr-free steel, a specimen quenched into water only shows no yield elongation but high yield strength. These results indicate that the low yield and high tensile strengths can be produced by giving a proper heat treatment to $0.5 \% \mathrm{Cr}$ steel.

\section{Holding Time}

$0.5 \% \mathrm{Cr}$ steels were annealed at $800^{\circ}$ or $900^{\circ} \mathrm{C}$ for 0 to $600 \mathrm{sec}$ and cooled at the rate of $25^{\circ} \mathrm{C} / \mathrm{sec}$. As shown in Fig. 4, the yield and the tensile strengths do not depend on the annealing time at $800^{\circ} \mathrm{C}$ while the yield strength increases gradually with increasing time at $900^{\circ} \mathrm{C}$.

Effects of annealing temperature and cooling rate on the tensile properties of $0.5 \% \mathrm{Cr}$ steel are summarized in Fig. 5. Numbers in the figure show the yield strength, the tensile strength, the yield ratio, and the yield elongation. Solid lines show the equi-property curves. The tensile properties of low temper-

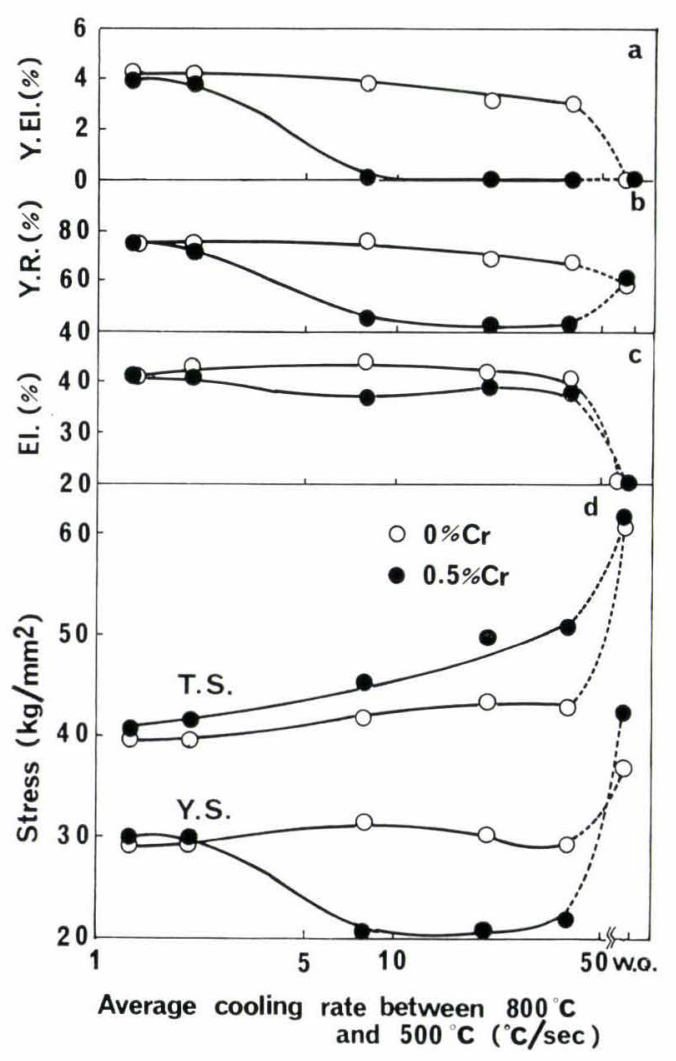
(a) yield elongation
(c) total elongation
(b) yield ratio
(d) tensile strength and yield strength

W.Q.: water quench

Fig. 3. Effects of cooling rate after annealing and $\mathrm{Cr}$ content on the tensile properties 


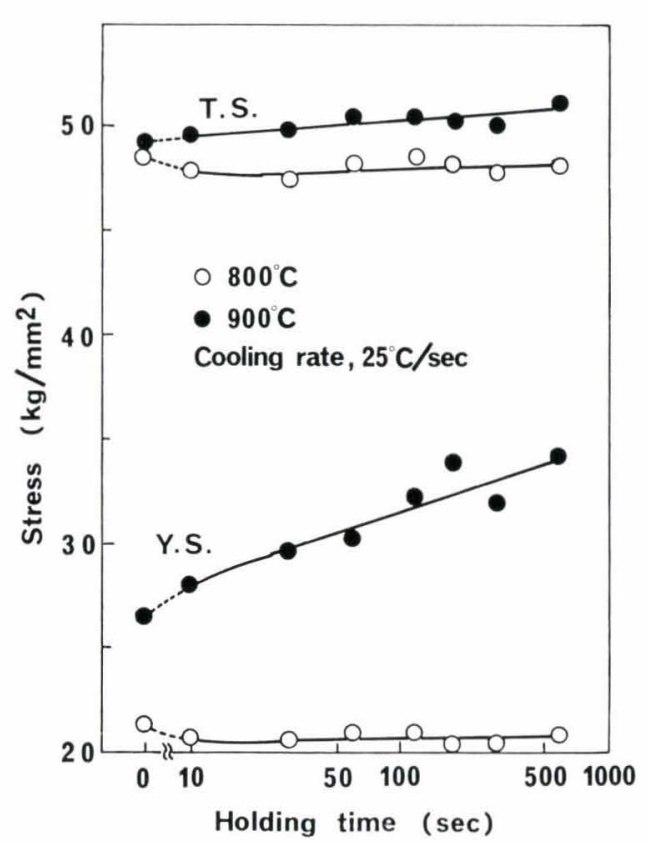

Fig. 4. Effect of holding time at the annealing temperature on the tensile properties

ature annealed and rapidly cocled specimens are nearly equal to those of high temperature annealed and slowly cooled ones. Yield elongation is almost diminished in the steel after annealing at the temperature higher than $750^{\circ} \mathrm{C}$ and cooled at the rate higher than $5{ }^{\circ} \mathrm{C} / \mathrm{sec}$. There are critical curves which divide tensile properties into two types; below these curves (the hatched part), i.e., at lower annealing temperature or lower cooling rate, yield strength and yield-to-tensile strengths ratio become higher. On the other hand, just above these curves, i.e., at high annealing temperature or high cooling rate, yield-to-tensile strengths ratio becomes very low. With further increase in annealing temperature or cooling rate, yield and tensile strengths gradually increase. Therefore, the lowest yield-to-tensile strengths ratio is obtained by annealing at $750^{\circ}$ to $800^{\circ} \mathrm{C}$ and cooling rate of $10^{\circ}$ to $50^{\circ} \mathrm{C} / \mathrm{sec}$. Within these annealing conditions, the yield and the tensile strengths are 19 to $21 \mathrm{~kg} / \mathrm{mm}^{2}$ and 44 to $50 \mathrm{~kg} / \mathrm{mm}^{2}$, respectively, which result in yield ratio of 41 to $45 \%$. Total elongation in these cases are in the range of 34 to $37 \%$.

Photographs 1 and 2 show the microstructures of the $0.5 \% \mathrm{Cr}$ steels annealed at various temperatures and cooling rates. The sheets annealed at $700^{\circ} \mathrm{C}$ and cooled at a rate of $8^{\circ} \mathrm{C} / \mathrm{sec}$ or annealed at $800^{\circ} \mathrm{C}$ and cooled at a rate of $0.8^{\circ} \mathrm{C} / \mathrm{sec}$ have ferrite and pearlite structure, whereas the sheets annealed under the other conditions reveal no yield elongation and have a "dual phase" structure consisting of the ferrite and a transformed phase of a high dislocation density reported as martensite ${ }^{6)}$ or tempered martensite. ${ }^{7)}$

Using a low $\mathrm{C}-\mathrm{Si}-\mathrm{Mn}$ steel, Hayami et al. ${ }^{6}{ }^{\text {) }}$ reported the formation of a dual phase structure which was consisted of uniformly mixed ferrite and martensite phases after continuous annealing at the $\alpha+\gamma$ temperature range followed by air cooling and the

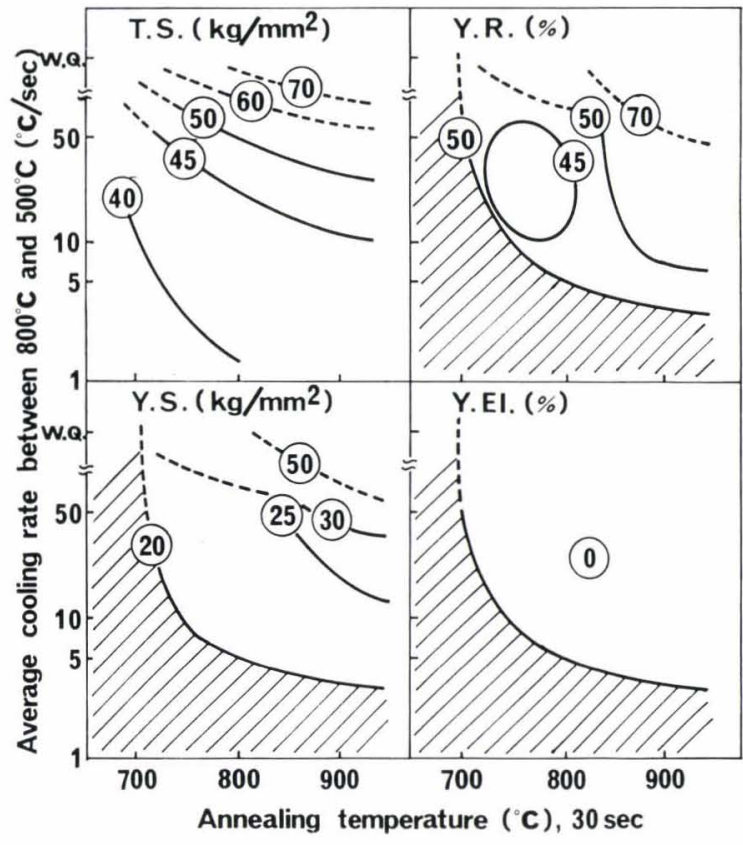

Fig. 5. Effects of annealing temperature and cooling rate on the tensile properties

low yield strength characterities of the products. Nakaoka et $a .^{7,8)}$ also reported a dual phase steel obtained by annealing at temperatures between $A_{1}$ and $A_{3}$ followed by water quenching and tempering at $200^{\circ}$ to $300^{\circ} \mathrm{C}$. The dual phase steel reported by Nakaoka et al. did not show the low yield characteristics. These dual phase steels gave bake-hardening or accelerated aging characteristics like the present one.

In the present case, however, the selection of chemical composition ( $\mathrm{Mn}$ and $\mathrm{Cr}$ ) and the proper control of cooling rate make it possible to avoid the tempering process after cooling from the annealing temperature, and consequently the pattern of annealing cycle is very simplified and the addition of large amount of $\mathrm{Si}$ and $\mathrm{Mn}$ can be avoided.

The transformation temperature $A c_{1}$ of $0.5 \% \mathrm{Cr}$ steel is about $730^{\circ} \mathrm{C}$, which corresponds to the critical temperature in Fig. 5, and $A c_{3}$ is about $880^{\circ} \mathrm{C}$. Therefore, it is suggested that the annealing at the temperatures higher than $A c_{1}$ and subsequent cooling with properly rapid rates are necessary to give the dual phase structure accompanying no yield elongation.

The amount and distribution of the transformed phase are changed depending on annealing conditions. Cooling from the $\alpha+\gamma$ temperature region, for example $800^{\circ} \mathrm{C}$, the microstructure contains fine transformed phase grains of less than $5 \mu \mathrm{m}$ within ferrite grains and/or along the ferrite grain boundary. When the specimen is cooled from the annealing temperature region higher than $900^{\circ} \mathrm{C}$ which is austenite region, the bainitic transformed structure is obtained.

Figure 6 shows the variation in yield and tensile strengths with the volume fraction of transformed phase after annealing calculated by the point-counting method. The yield strength vs. volume fraction of the transformed phase curve shows that the yield strength decreases from 0 to $2 \%$ of the transformed 


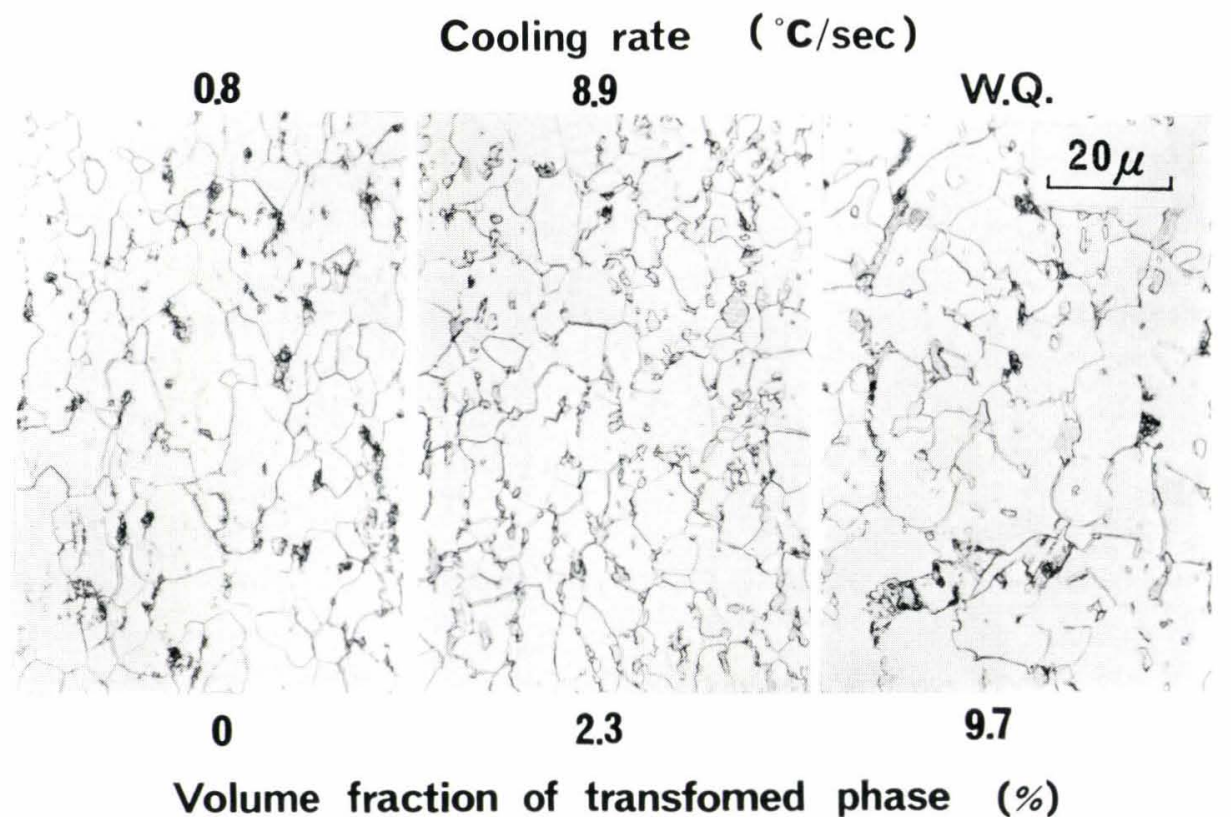

Annealing at $800^{\circ} \mathrm{C}$ for $30 \mathrm{sec}$

Photo. 1. Effect of cooling rate after annealing on the microstructure and the amount of transformed phase of cold rolled low $\mathrm{C}-\mathrm{Mn}-\mathrm{Cr}$ steel

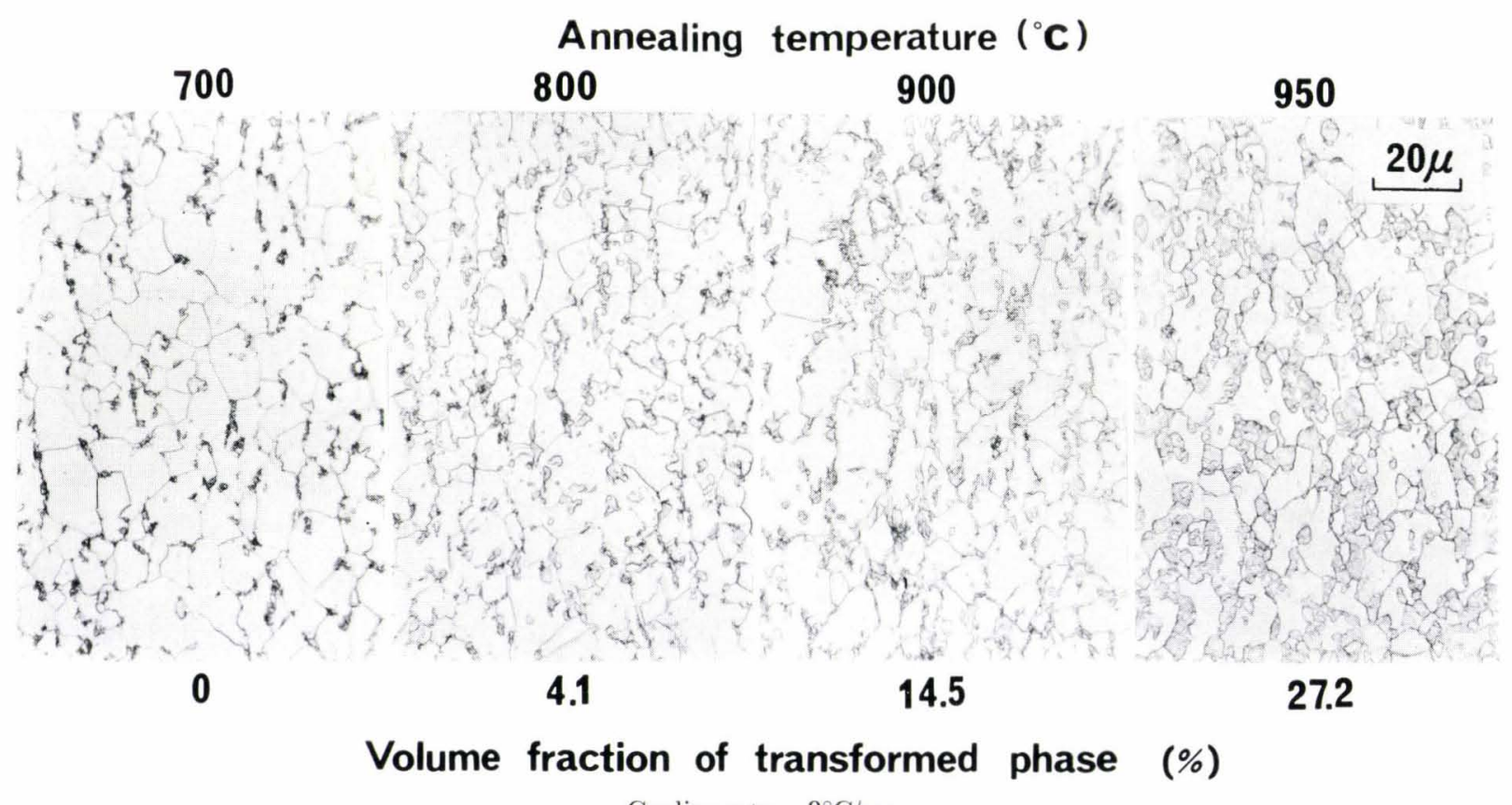

Cooling rate: $8^{\circ} \mathrm{C} / \mathrm{sec}$

Photo. 2. Effect of annealing temperature on the microstructure and the amount of transformed phase of coldrolled low $\mathrm{C}-\mathrm{Mn}-\mathrm{Cr}$ steel

phase, reaches the minimum at 2 to $5 \%$ and increases with further increase in the volume fraction. On the other hand, the tensile strength increases very steeply with increase in the volume fraction of transformed phase in the range of 0 to $5 \%$ and increases gradually above $5 \%$ of the phase.

\section{Press Formability}

On the basis of the laboratory experiments described above, the low yield and high tensile strengths cold-rolled steels have been produced in a commercial production process. Typical mechanical properties of the steels are shown in Table 1. The basic composition of the steel is $0.05 \% \mathrm{C}-1.2 \% \mathrm{Mn}-0.5 \% \mathrm{Cr}$. Since the short time annealing at the temperature above $A_{1}$ and the proper cooling rate were necessary to give the low yield and high tensile strengths, continuous annealing was carried out by using a bright annealing line ${ }^{9)}$ for stainless steel strips which consists of the rapid heating, short time holding, and gas jet cooling zones. These steels exhibit no yield elongation and have a tensile strength of 45 to $70 \mathrm{~kg} / \mathrm{mm}^{2}$, 
giving the yield-to-tensile strengths ratio of less than $60 \%$ and consequently very high work hardening rates.

\section{Aging Properties}

One of the steels in Table 1, CR50, was aged at the temperature range of $100^{\circ}$ to $600^{\circ} \mathrm{C}$ for $20 \mathrm{~min}$ with or without $5 \%$ prestraining.

The tensile properties after aging are shown in Fig. 7. Without prestraining, the yield elongation does not appear and the changes in yield strength and tensile strengths are slight by the aging below $200^{\circ} \mathrm{C}$, while by the aging above $200^{\circ} \mathrm{C}$ yield elongation appears, yield strength increases and tensile strength decreases. The maximum yield strength is obtained by the aging at $400^{\circ} \mathrm{C}$, and the increase in the strength compared to that of as-annealed steel is 10 to 15 $\mathrm{kg} / \mathrm{mm}^{2}$. On the other hand, strain aging increases yield strength as well as the tensile strength and the maximum yield strength is obtained by the aging at $250^{\circ} \mathrm{C}$. The effect of prestraining on the tensile properties after aging at $170^{\circ} \mathrm{C}$ for $20 \mathrm{~min}$ is shown in Fig. 8; these aging conditions simulate the paint baking process for automobile making. With increasing prestrain, yield and tensile strengths after aging increase, but the increase in the yield strength due to

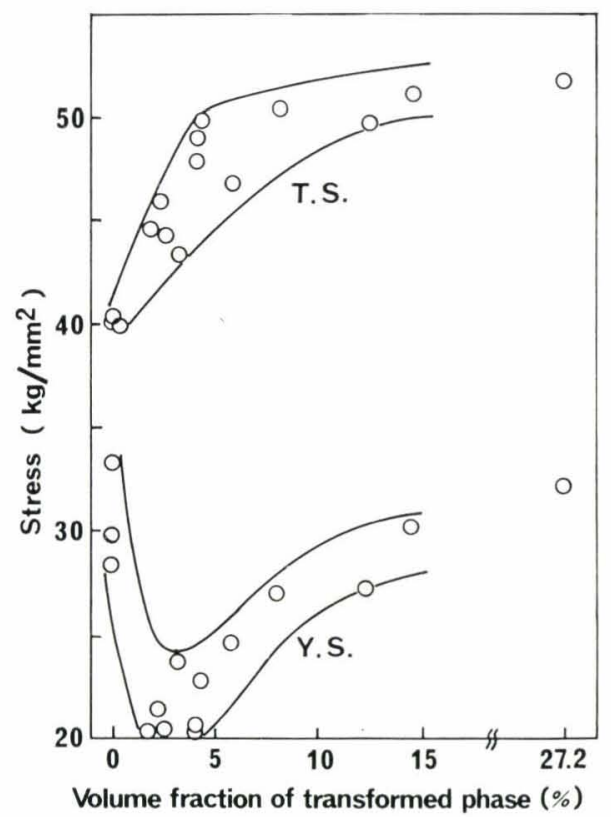

Fig. 6. Relations between the volume fraction of transformed phase and the tensile and yield strengths aging itself $\left(\Delta \sigma_{A}\right)$ does not depend on the amount of prestrain and the value is about 5 to $10 \mathrm{~kg} / \mathrm{mm}^{2}$.

\section{Formability}

Figure 9 shows the conical cup value (C.C.V.), limiting drawing ratio (L.D.R.), bulge height, and total elongation as a function of the tensile strength. In the figure, the properties of mild steels having the tensile strengths of 30 and $33 \mathrm{~kg} / \mathrm{mm}^{2}$ and box-annealed high tensile strength steels are also shown for comparison. The box-annealed high tensile strength steels, low $\mathrm{C}-\mathrm{Si}-\mathrm{Mn}$ or low $\mathrm{C}-\mathrm{Si}-\mathrm{Mn}-\mathrm{Nb}$ steel, have the yield to tensile strengths ratios higher than 0.7 which are higher than those of continuously annealed low C-Mn-Cr steels.

Elongation and bulge height of continuously annealed low yield and high tensile strengths steels are larger than those of box-annealed steels at the same strength level. On the other hand, the C.C.V. does not depend so much on the annealing methods and increases with increasing in the strength. L.D.R. is

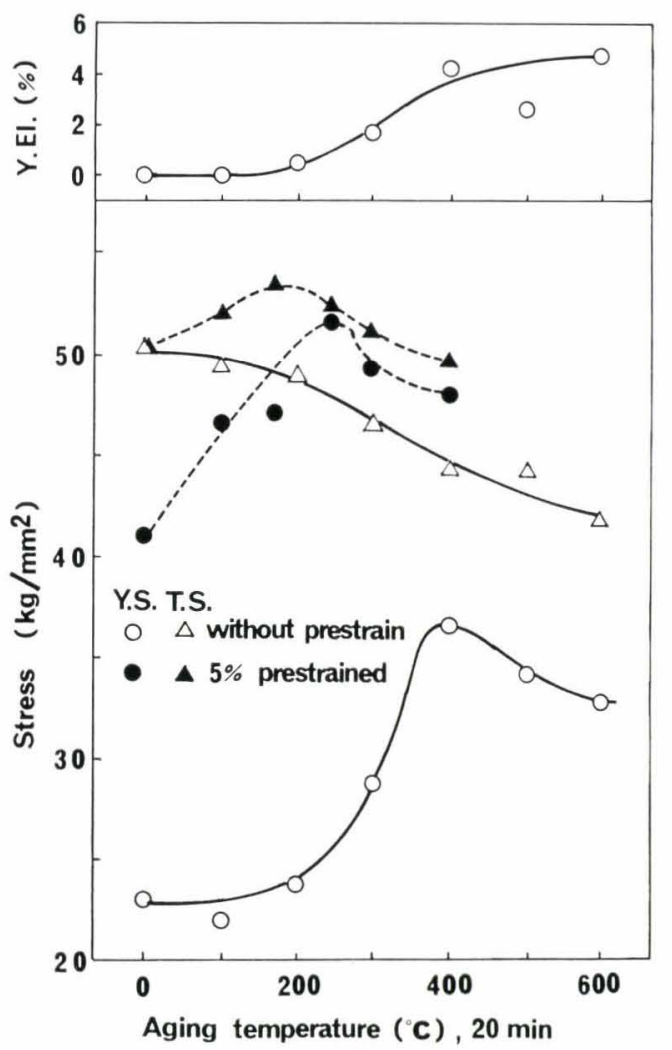

Fig. 7. Age-hardenability of the sheets at various temperatures after $5 \%$ straining or without straining

Table 1. Chemical compositions and mechanical properties of low yield-to-tensile strength cold-rolled sheet steel (Thickness : 0.8 mm)

\begin{tabular}{|c|c|c|c|c|c|c|c|c|c|}
\hline \multirow[b]{2}{*}{ Grade } & \multicolumn{4}{|c|}{ Chemical composition (wt \%) } & \multicolumn{5}{|c|}{ Mechanical properties } \\
\hline & $\mathrm{C}$ & $\mathrm{Si}$ & $\mathrm{Mn}$ & $\mathrm{Cr}$ & $\begin{array}{c}\text { Y.S. } \\
\left(\mathrm{kg} / \mathrm{mm}^{2}\right)\end{array}$ & $\begin{array}{c}\text { T.S. } \\
\left(\mathrm{kg} / \mathrm{mm}^{2}\right)\end{array}$ & $\begin{array}{c}\text { El. } \\
(\%)\end{array}$ & $r$ value & $n$ value \\
\hline CR45 & 0.051 & 0.030 & 1.22 & 0.52 & 22.7 & 49.7 & 35 & 0.81 & 0.241 \\
\hline CR50 & 0.045 & 0.50 & 1.22 & 0.47 & 25.3 & 53.0 & 33 & 0.80 & 0.246 \\
\hline CR60 & 0.071 & 0.035 & 1.26 & 0.49 & 39.5 & 62.9 & 29 & 0.89 & 0.178 \\
\hline CR70 & 0.062 & 0.52 & 1.26 & 0.50 & 43.8 & 69.6 & 26 & 0.86 & 0.170 \\
\hline
\end{tabular}




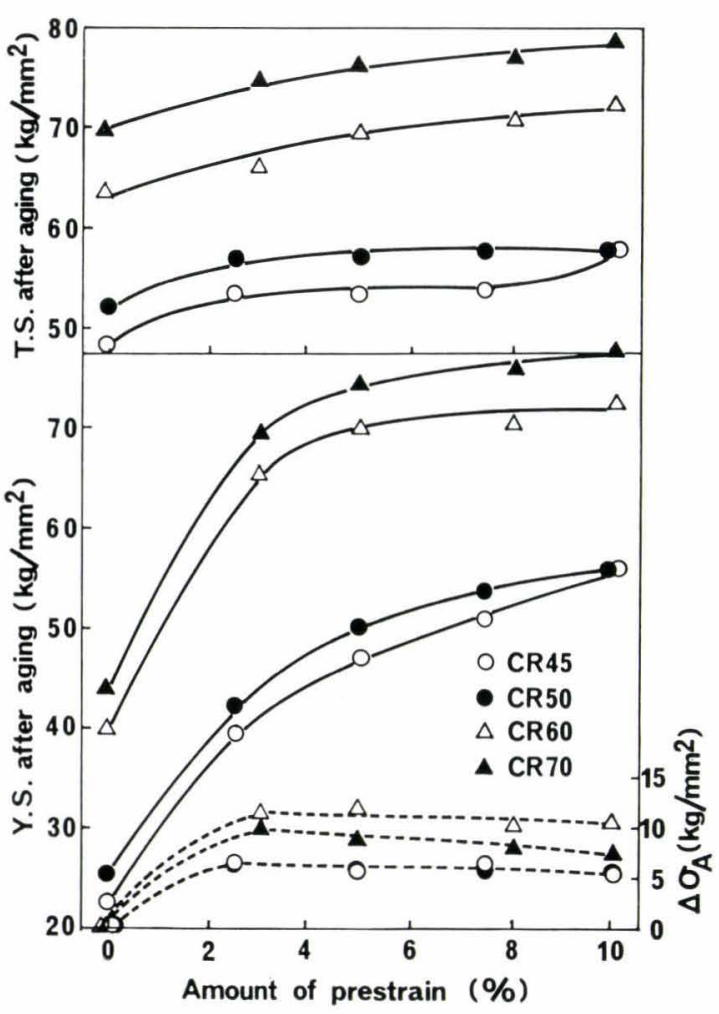

$\Delta \sigma_{A}:$ increase in yield strength by aging

Fig. 8. Effect of prestraining on the tensile properties after aging at $170^{\circ} \mathrm{C}$ for $20 \mathrm{~min}$

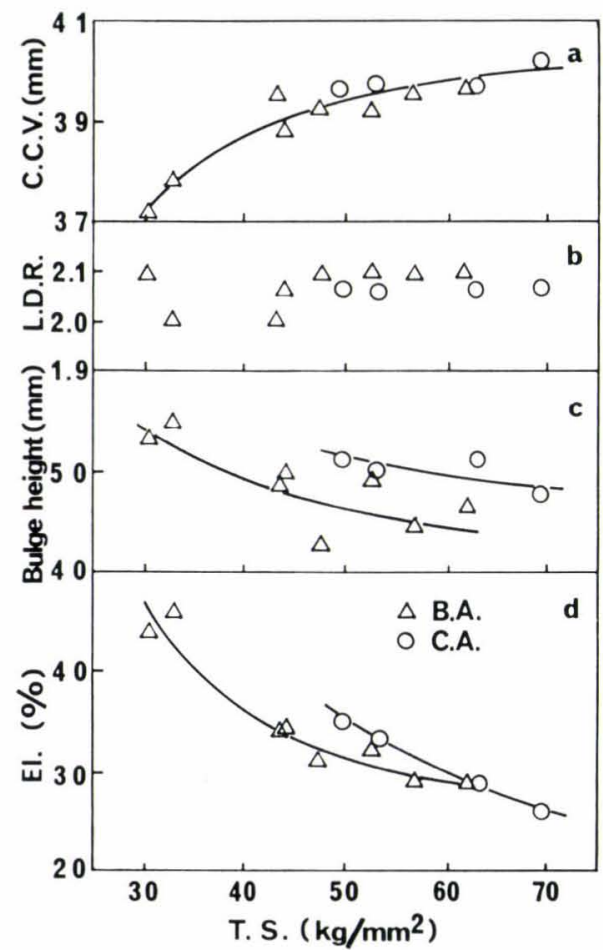

B.A.: box-annealed steels

C.A.: continuously annealed low $\mathrm{C}-\mathrm{Mn}-\mathrm{Cr}$ steels C.C.V.: conical cup value

L.D.R.: limiting deawing ratio

Fig. 9. Changes of (a) C.C.V., (b) L.D.R., (c) bulge height and (d) total elongation as a function of tensile strength

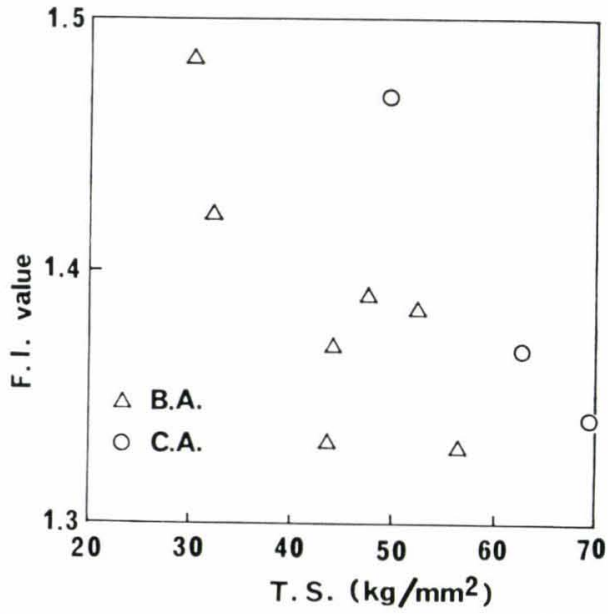

Fig. 10. Relation between $F I$ value $^{10}$ and tensile strength

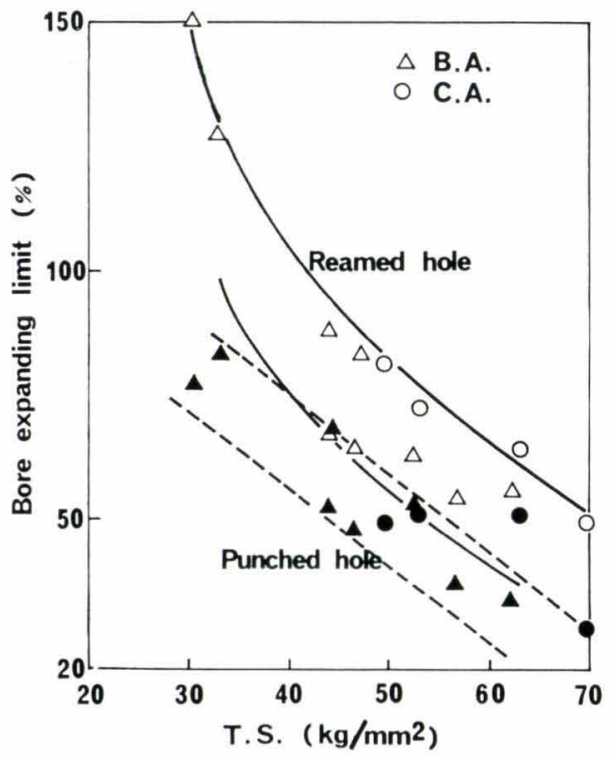

Fig. 11. Relation between bore expanding limit and tensile strength

not affected by the strength.

The conical cup buckling test (C.C.B.T.) which is proposed by Abe and Nakagawa ${ }^{10}$ to evaluate the tendency of the formation of wrinkle and breakage on press forming was carried out. The $F I$ value which is defined to express this tendency ${ }^{10)}$ is shown in Fig. 10; the values for continuously annealed steels are higher than those of box-annealed ones.

Bore expanding limits of the specimens with reamed or punched holes are plotted against the tensile strength in Fig. 11. Bore expanding limits of the specimens with reamed or punched hole decrease with increasing the tensile strength. The stretch flangeability generally depends on the mechanical fiber such as non metallic inclusions or carbides in steel in the case of hot-rolled strips and on the crystallographic orientation in the case of cold-rolled and annealed strip. In the latter case, the necking position in bore expanded specimen closely corresponds to the direction showing the minimum plastic strain ratio. There is a large scattering in the data, but it is found that bore expanding limit is roughly proportional to the value of 


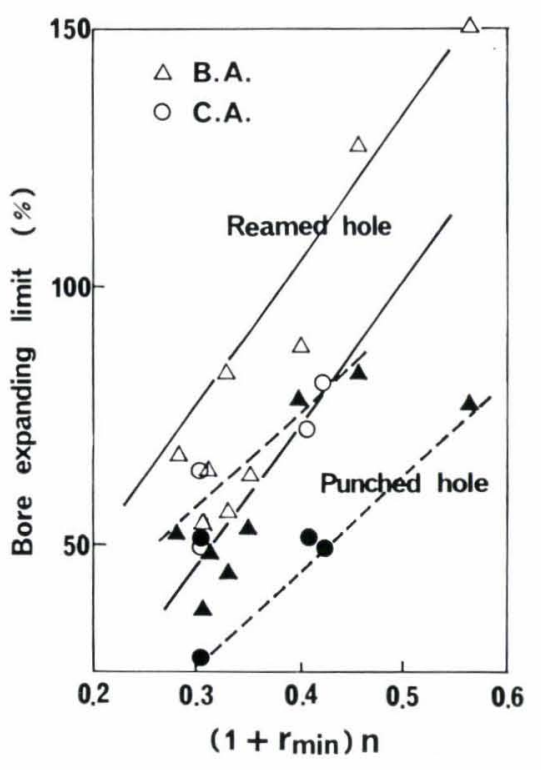

Fig. 12. Relation between bore expanding limit and $(1+$ $\left.r_{\min }\right) n$ value

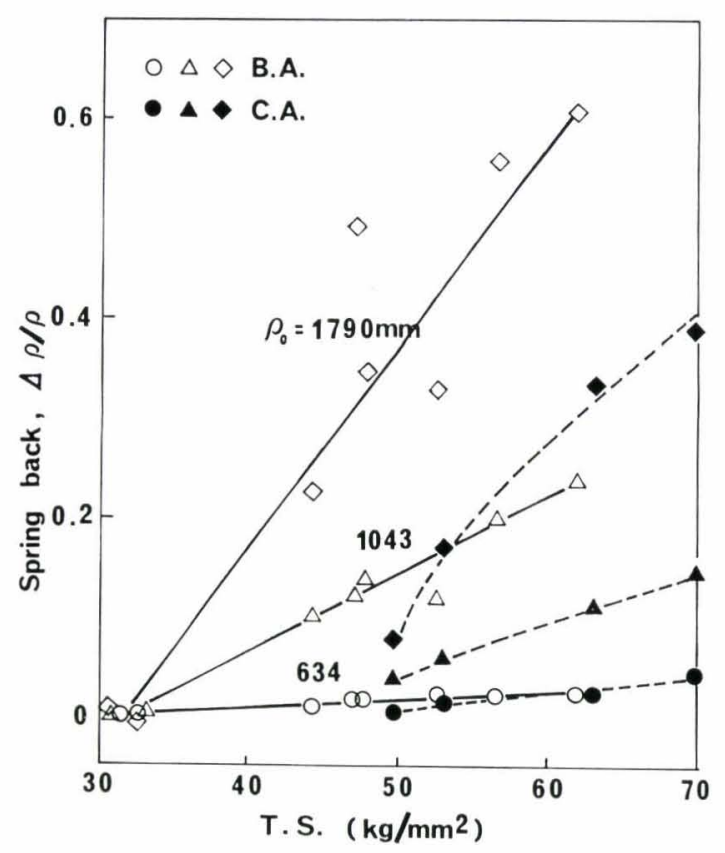

Fig. 13. Relation between tensile strength and the amount of spring back, $\Delta \rho / \rho$, after light press forming with various punch radii, $\rho$ 。

$\left(1+r_{\min }\right) n$ as for the results of mild steels ${ }^{11)}$ as shown in Fig. 12.

\section{Shape-fixability}

Press forming was performed to make square cylinders with a side of $300 \mathrm{~mm}$, depth of $50 \mathrm{~mm}$, the bottom having three different curvature radii. Spring back in the bottom surface is plotted against tensile and yield strengths in Figs. 13 and 14, respectively. Spring back, $\Delta \rho / \rho$, is defined as $\left[\left(1 / \rho_{\circ}\right)-(1 / \rho)\right] /\left(1 / \rho_{\circ}\right)$ where $\rho_{\mathrm{o}}$ is radius of curvature of punch bottom and $\rho$ is that of the bottom of pressed part. When $\rho_{\circ}$ is large, the spring back in box-annealed steels is proportional to the tensile strength of the sheets, whereas that of

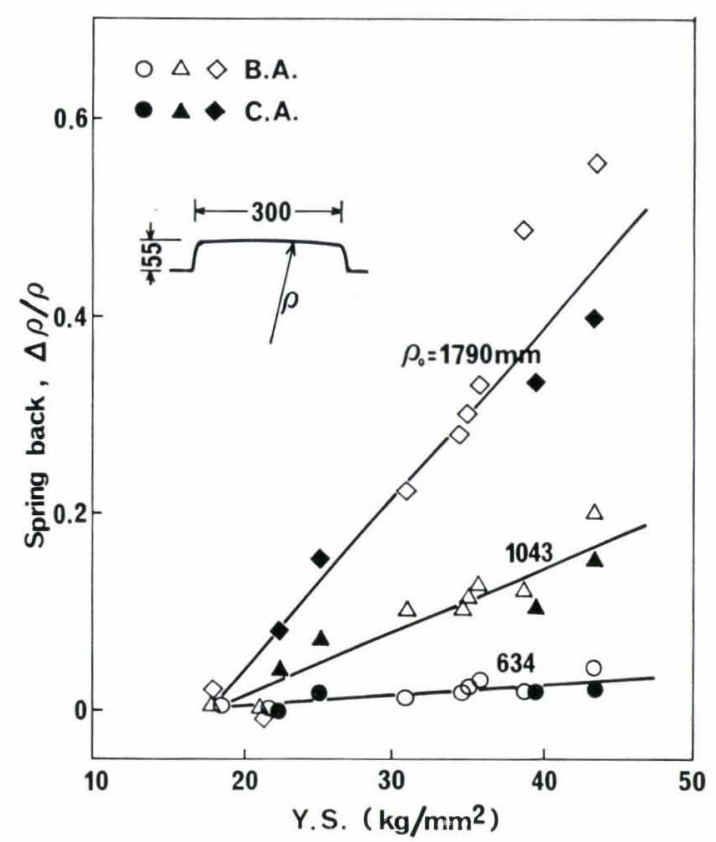

Fig. 14. Relation between yield strength and the amount of spring back, $\Delta_{\rho} / \rho$, after light press forming with various punch radii, $\rho_{0}$

the continuously annealed steels of low yield and high tensile strengths is nearly half that of box annealed ones at the same strength level.

Since the spring back of the both types of steel related linearly to the yield strength as shown in Fig. 14, low yield strength steels are favorable to make a press forming of large radius of curvature, for example, as car body panels. It is well known that the decrease in spring back is very effective to increase in the rigidity of pressed parts especially of large radius of curvature. ${ }^{12,13)}$

The dent resistance was tested by compressing the center of the bottom surface of the above described pressed part to give the deflection of $5 \mathrm{~mm}$. The residual deflection (permanent strain) after unloading was measured and shown in Fig. 15. With increasing the yield strength and decreasing the surface curvature, the residual deflection decreases and at the same yield strength level residual deflection of continuously annealed steels are smaller than those of box-annealed ones.

Since the pressed parts made of continuously annealed steels were aged at $170^{\circ} \mathrm{C}$ for $20 \mathrm{~min}$, residual deflections became smaller due to the increase in the yield strength by strain age hardening.

\section{Static Crash Resistance of Hat-shaped Structure}

A hat-shaped structure was formed by pressing, at the rims of which a bottom sheet was seam welded to make box type structure for simulating the reinforcement of the automobiles. The structures asformed or aged at $200^{\circ}$ or $400^{\circ} \mathrm{C}$ were deformed by plane compression. The typical load deflection curve is schematically shown in Fig. 16. The buckling load, $P_{\mathrm{B}}$ and absorbed energy, $Q$ are calculated and shown in Fig. 17. The buckling load increases with increasing the yield strength and becomes larger for aged 


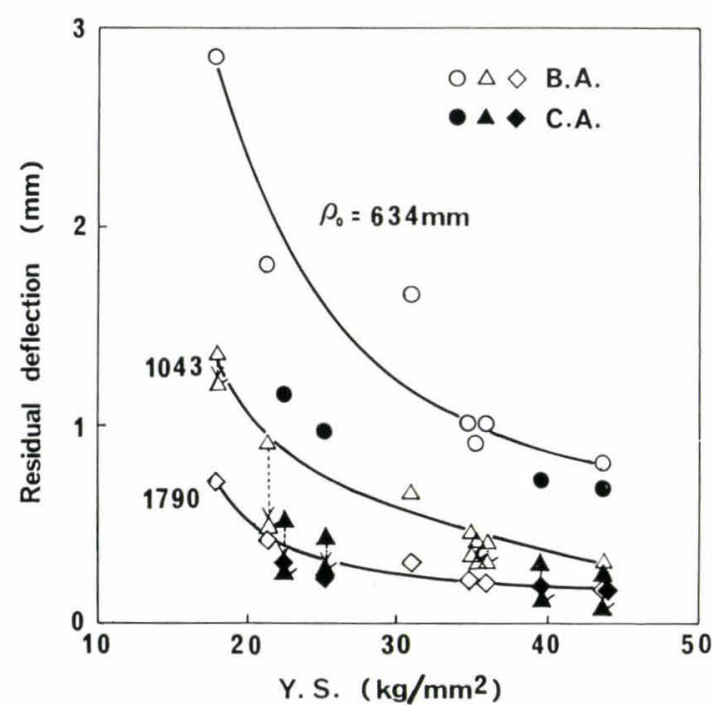

$\Delta, \boldsymbol{\Delta}$ : aged at $170^{\circ} \mathrm{C}$ for $20 \mathrm{~min}$ after press forming

Fig. 15. Effects of yield strength and punch radius, $\rho_{\circ}$, on the residual strain after local compression of pressed parts

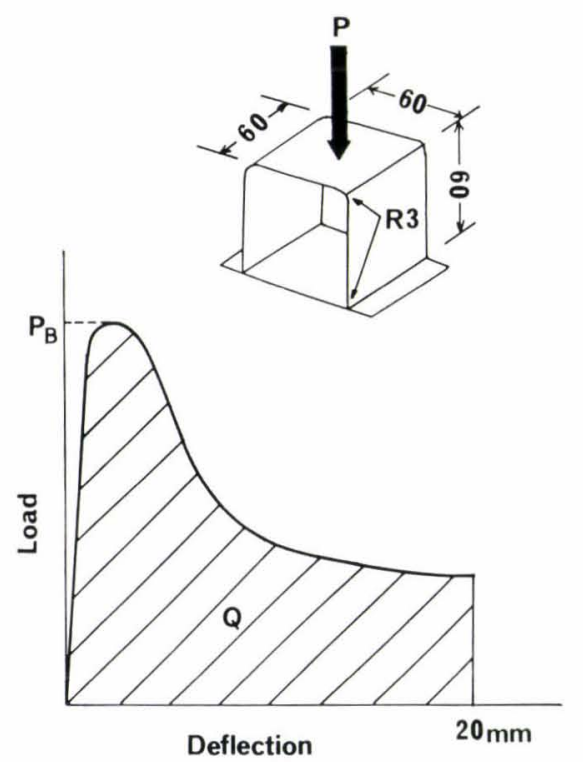

$P_{B}$ : buckling load $Q$ : absorbed energy

Fig. 16. Schematic diagram of deflection-load curve of a hat-shaped structure made of HSCR sheet steel

structures than for as-formed ones. There is no difference, however, in the increase in the buckling load due to age hardening at $200^{\circ} \mathrm{C}$ between continuously annealed high tensile strength steels and box-annealed mild steels. Buckling loads of continuously annealed steels aged at $400^{\circ} \mathrm{C}$ become larger than those of the ones aged at $200^{\circ} \mathrm{C}$. The absorbed energy for collapse is proportional to the tensile strength and it becomes large by aging as in the case of the buckling load.

\section{Conclusions}

The low yield and high tensile strength $(40 \sim 70$ $\mathrm{kg} / \mathrm{mm}^{2}$ ) low $\mathrm{C}-\mathrm{Mn}-\mathrm{Cr}$ steels have been developed

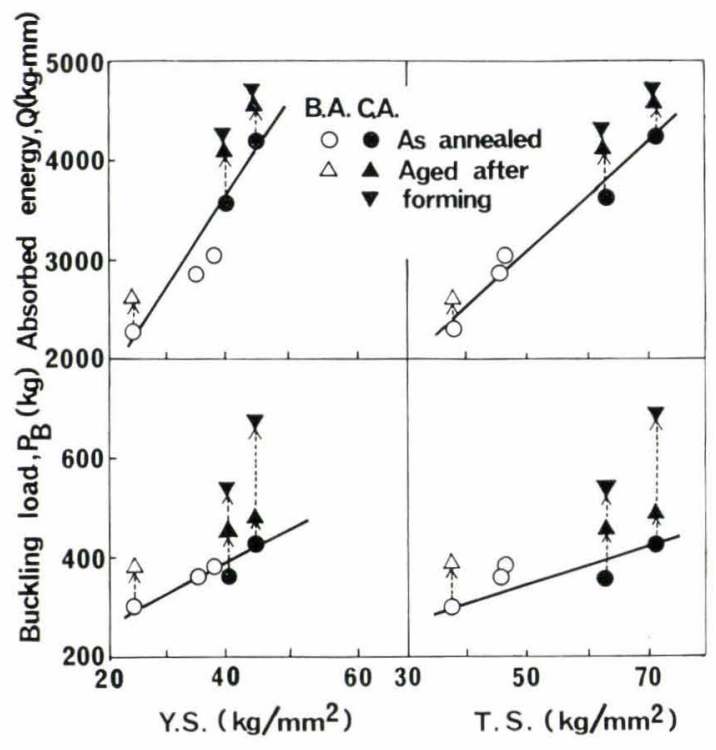

Arrows show aging treatment at $200^{\circ} \mathrm{C}(\boldsymbol{\Delta})$ and $400^{\circ} \mathrm{C}(\boldsymbol{\nabla})$,

Fig. 17. Effects of yield strength, tensile strength and aging treatment on the buckling load and absorbed energy

by using continuous annealing above $A_{1}$ temperature. These steels have a dual phase structure which is consisted of ferrite grains and transformed phase grains smaller than $5 \mu \mathrm{m}$ which have a very high dislocation density. The minimum yield strength is obtained with 2 to $5 \%$ of the transformed phase in the structure.

The mechanical properties of these steels are summarized as follows.

(1) The steels do not exhibit a discontinuous yield drop and give a low yield-to-tensile strengths ratio of less than $60 \%$.

(2) Tensile properties of as-annealed sheets are not changed by a simple aging below about $200^{\circ} \mathrm{C}$. The yield strength remarkably increases, however, by the aging at $400^{\circ} \mathrm{C}$.

(3) The increase in the yield strength due to strain aging is very large and the maximum increase is obtained by the aging at about $250^{\circ} \mathrm{C}$ after several percent strain. This high strain aging hardenability, "bake-hardenability", is beneficial to strengthen the pressed parts during paint baking process after the press forming.

(4) The good shape-fixability, especially for the pressed parts of large radii of curvature, is due to the low yield strength characteristics of these steels.

\section{REFERENCES}

1) S. Hanai and T. Satoh: J. Japan Soc. for Technology of Plasticity, 15 (1974), 885.

2) K. Yoshida: J. The Society of Automotive Engineers of Japan, 30 (1976), 108.

3) K. Hashiguchi, I. Takahashi and N. Ōhashi: Tetsu-toHagané, 60 (1974), S488.

4) K. Hashiguchi, I. Takahashi and N. Ōhashi: Tetsu-toHagané, 61 (1975), S773.

5) B. S. Levy: Blast Furnace \& Steel Plant, 59 (1971), 149.

6) S. Hayami and T. Furukawa: Proceedings of Microalloying 75, Union Carbide Corp., New York, (1975), 311.

7) K. Nakaoka, K. Araki, K. Iwase, K. Uchida and S. Fuku- 
naka: Tetsu-to-Hagané, 61 (1975), S150.

8) K. Nakaoka, K. Araki, K. Kurihara and S. Fukunaka: Tetsu-to-Hagané, 61 (1975), S571.

9) S. Urayama, A. Kamiya and Y. Konishi: Kawasaki Steel Technical Report, 4 (1972), 49.

10) H. Abe and K. Nakagawa: Preprint of Japan Associated Conference on Plastic Technology in the spring of 1975,
(1975), 121

11) Y. Itō and K. Hashiguchi: Kawasaki Steel Technical Report, 3 (1971), 389.

12) K. Takahashi and K. Nakajima: J. Japan Soc. for Technology of Plasticity, 6 (1965), 674.

13) H. Abe and K. Nakagawa: Kawasaki Steel Technical Report. 5 (1973), 210 